О.М. Рубанець,

доктор філософських наук, професор НТУ України «КПI»

\title{
КОГНІТИВНІ ОСОБЛИВОСТІ ВІДТВОРЕННЯ ОБ'ЄКТА В ЗНАННІ
}

Відтворення об'єкта в знанні пов'язане зі здійсненням різноманітних детермінацій. Найважливішими з них є детермінації об’єкта й теорії, предметна область якої характеризує основні закономірності досліджуваних явищ. Детермінація досліджуваного об'єкта може реалізовуватись методологічно - через філософсько-категоріальні настанови, що передують здійсненню дослідження.

Онтогносеологізм Київської школи (А.Артюх, П.Копнін та ін.) виокремлює категоріальні передумови дослідження об'єкта, розкриваючи їх як категорії культури. Перехід від класичної до некласичної гносеології зумовив необхідність розгляду комунікативної взаємодії суб'єкта з об'єктом (І. Черникова). У філософію науки було уведено комунікативно-біхевіоральний аспект мовних взаємодій. Осягнення його як соціальних практик, що спотворюють гносеологічне відношення, спонукав В.Рорті відмовитися від Дзеркала природи.

Соціальний аспект комунікативної взаємодії у повному вигляді дебатів зафіксувала французька історична школа. Дослідження нею впливу соціально-лабораторних взаємодій на відтворення в знанні об'єкта стало основою визнання соціального як форми його (об’єкта) відтворення. Вплив соціального і культурного контексту на теоретичні конструкти та пізнавальну ситуацію загалом $є$ рисою соціального конструктивізму.

Протиставленість детермінації об'єкта детермінації соціальних конструкцій та соціальних практик унагальнює питання про необхідність виявлення такої детермінації, у якій процеси відтворення об'єкта у знанні не були б класичними, дзеркальними і водночас утримували знання та розв'язання в ньому завдань адекватності його об'єкту в межах сучасної постнекласичної методологічної ситуації.

Постнекласика, як характеристика сучасної методологічної ситуації на рівні об'єкта, визначає специфіку об'єктів постнекласичної 
науки. В.Стьопін, досліджуючи об'єкти постнекласичної науки як людиновимірні системи, наголошував на відмінності режимів функціонування та розвитку. Однак потрібно звернути увагу на те, що людиновимірність об'єктів постнекласичної науки є характеристикою всезагального: людиновимірними є не тільки соціальні та суспільні системи, а й технічні (технічні системи прийняття рішень, людино-машинні системи та людино-машинні середовища, соціотехнічні системи та соціотехнічні ландшафти тощо).

Постнекласичність природних систем дістає своє вираження у їх системних характеристиках теоретичної експлікації об'єкта в знанні, насамперед - в цілісності, нелінійності, самоорганізації, наявності хаотичних режимів та режимів загострень та ін.

Відтак на перше місце у розкритті об'єкта виходить не притаманна об'єкту властивість, а спосіб репрезентації об' єкта в знанні як системи або мережі. Впровадження в розгляд когнітивних особливостей відтворення об'єкта у знанні зумовлює необхідність досліджувати поряд із детермінацією об'єкта та соціальними комунікаціями особливо недосліджений вид знаннєвої детермінації способу відтворення об'єкта в знанні.

Знаннєва детермінація відтворення об'єкта в знанні полягає насамперед у розкритті способу його представлення та застосування на цій основі ідеальної предметності знання.

Насправді те, що структура об'єкта в знанні не відповідає власній структурі об'єкта, було відомо в логіці наукового дослідження. Адекватними структурі об'єкта чинниками лишалися лише ті, які визначають зміст предметної області теорії, а - саме ії закони. Така невідповідність змісту знання структурі об'єкта в природничонауковій теорії пояснювалась іiі, теорії, значною мірою формалізованою структурою - наявністю математичного апарату чи математичного формалізму. Розуміння якісної відмінності математичних формул і математичних рівнянь від структури досліджуваного об’єкта змушувало «відрізати» математичні теоретичні конструкти та загалом формалізовану частину природничонаукового знання від з'ясування адекватності знання об'єкту. Разом з тим зазначалося, що поняття предметної області теорії мають також формальноматематичну складову (В.Кураєв, Ф.Лазарев), а математична частина природничонаукового знання є складовою ідеалізованого теоретичного об’єкта (В.Кузнецов). 
Запровадження репрезентації з позицій соціального конструкціонізму (С. Московічі, П.Бурдьє) призводить до втрати зв'язку пізнавальних відносин з автономною від суспільства сферою знання, а відмова від точних репрезентацій у постмодерністській традиції - до відмови автономності пізнавальних відносин від соціальних інтересів та суспільних практик, фактично - до заперечення можливості пізнання як єднання людини з буттям.

Відокремлення лінгвістичного повороту в науці від когнітивного часто пов'язують із розглядом ментальних репрезентацій. Цим досягається перехід від реконструкції науки у вигляді текстових утворень, насамперед дискурсів, до розгляду когнітивної активності людини. Однак дослідження ментальної репрезентації показують неможливість її безпосереднього застосування в методологічних реконструкціях еволюції систем об'єктивного знання.

Запровадження ментальної репрезентації в когнітивній психології пов'язане з переходом від дослідницького поля в межах співвідношення стимулу і реакції в перших моделях до ідеології, згідно 3 якою «психічне» розробляється в межах опису стимулу, i далі до моделей другого покоління, в яких відбувається «ревізія вихідних когнітивістських припущень про примат змісту» [11, 27]. На перший план виходить «засвоєння суб'єктом цього психічного змісту» $[11,27] .3$ цим, згідно з Perner (1997), пов'язується внесок когнітивної психології в пояснення відмінностей між знанням, мисленням і запам'ятовуванням $[11,27]$.

Найссер, з'ясовуючи розвиток дослідження когнітивної активності $[7,71]$ як протилежностей, наводить розгляд Гібсона «в термінах структури середовища» $[7,72]$, в якому все, включаючи схему, уявляється «небезпечно менталістським» [7, 72], і погляди представників крайніх варіантів теорії перероблення інформації чи конструктивістських концепцій, яких «мало цікавить те, яку саме інформацію містить реальне середовище. Вони, так би мовити, лишають того, хто сприймає, таким, який заплутався у власній системі переробки інформації...» [7, 72]. В.Дем'янков, розглядаючи когнітивізм як такий, що досліджує людину як систему переробки інформації» $[4,17]$, вважає істотним відокремлення ментального від нейронного, протиставляючи його біхевіоризму та нейропсихології: «На відміну від цих підходів, когнітивісти прагнуть формулювати свої гіпотези в термінах самих ментальних процесів... в 
абстракції від матеріальної реалізації в мозку» [4, 17-18]. Дослідження ментальної репрезентації як способів переробки інформації пов'язане з операціями в психологічному просторі. Перехід до узагальнених моделей відбувається «шляхом генералізації якоїсь когнітивної операції...» $[11,25]$. Якби відтворення певної онтологічної природи ментальної репрезентації було провідною ідеєю, то встановлення зв'язку між моделями було б можливим. Але тільки окремі автори дійшли висновку, що теорії на семантичних ознаках можуть бути переведені в мережі (Д.Енгелькамп та ін., 1988).

У розгляді розробки ментальної репрезентації як формату зберігання інформації йдеться про те, що «ментальна репрезентація не $\epsilon$ терміном, який описує зміст психічного відображення» $[11,28]$. Так, Т.Ребеко, посилаючись на Д.Енгелькампа і М.Дені (1989), стверджує, що сьогодні існує точка зору, що ментальні репрезентації - це структурні елементи системи переробки інформації, до яких додаються деякі операції $[11,5]$. У проекті Стенфордського університету ментальна репрезентація розглядається як об'єкт із семантичними властивостями [17]. Пітт (Pitt), визнаючи важливість досягнень когнітивної науки, визнає різний ступінь обізнаності 3 цими досягненнями та включеності їх у філософські дослідження. Репрезентаційні теорії орієнтовані на пропозиційний зміст повсякденного мислення. Нерозв'язаною лишається проблема вираження змісту ментальних репрезентацій як такого, що складається з абстрактних об'єктів, оскільки останні не можна виразити в термінах, якими описуються мозок і центральна нервова система. Співвідношення репрезентаціонізму і феноменалізму пролягає через визнання чи заперечення можливості редукції ментальних станів до видів інтенціонального змісту [17].

Спираючись на ідеї знакового характеру репрезентації, її безсубстратного подання в когнітивізмі та коннекціонізмі, ми вважаємо, що розгляд репрезентації потрібно перевести 3 виміру технічної активації свідомості (комп'ютерної метафори, мережевої активації) на розгляд знання як форми ідеального. Визнання об'єктивного існування, не залежного від людини та усвідомлення нею світу в контексті досліджень репрезентації, має стати основою введення у внутрішній простір знання законів, як найважливіших складових ідеалізованої предметності.

Дослідження когнітивної активності людини переводиться 3 
рівня людини як інформаційної системи на рівень демонстрації цієї активності у вигляді трансформації способу представлення об'єкта у знанні. Виведення на рівень сфери - системних перетворень в об'єктивному знанні, викликаних трансформацією репрезентації та розвитком оперативної компоненти об'єктивного знання, дозволяє ввести в розгляд системні прояви когнітивності, пов'язані 3 дією колективного суб'єкта у сфері знання. Досі представлення не вводились у значенні конститутивних компонентів знання в методологічні реконструкції, хоча звернення до репрезентативних властивостей та структури систем знання відзначалось у структуралістських реконструкціях $[6,23]$.

Запровадження ідеальної предметності знання в еволюційному вимірі дає можливість дослідити генетичні зв'язки між різними способами представлення об'єкта і розкривати цей перехід (від геометричної форми - до аналітичної) як трансгресію сфери знання внаслідок зміни виду репрезентації.

Протилежність конструктивізму та репрезентативізму $[1,81]$ не враховує когнітивного змісту відтворення об'єкта у знанні, пов'язаною з ідеальною предметністю наукового знання. Еволюційний підхід до системних проявів когнітивності в науці дає змогу перейти від розгляду репрезентаторів як замісників об'єкта у знанні до розкриття репрезентації як способу подання об’єкта у знанні на основі методологічної реконструкції його ідеальної предметності.

Те, що заміщення об'єкта у знанні породжує ідеальну предметність знання, добре видно на перших вихідних теоретичних моделях дослідження об'єктів динаміки. У «Бесідах та математичних доках» Г.Галілея розглянуто цикл проблем, пов'язаних із рухом тіл по похилій площині. Кожна задача містить фіксований у тексті безпосередній перехід від матеріального об'єкта - похилої площини та руху тіл по ній - до його репрезентації у вигляді однієї зі сторін прямокутного трикутника. Геометричний відрізок стає представленням руху тіла по похилій площині. Він постає у всезагальній геометричній формі відрізка як такого, величина якого фіксована не емпіричними процедурами вимірювання і не конкретними числовими розмірами. Всезагальність надається самим способом представлення руху в знанні на основі математичної пропорції - спільної для будь-яких емпіричних відрізків. Особливість цієї математичної форми полягає в тому, що іiі введення у спосіб подання об’єкта у

132 ISSN2078-8142Мультиверсум. Філософський альманах.-2015.-Випуск 3-4(141-142) 
знанні задає процесуальність знання, створює його внутрішній вимір, відмінний від природи об'єкта чи його прихованої сутності.

Ідеальна предметність знання є категорією, що розкриває об'єкт через спосіб його представлення у знанні. Вона виявляє внутрішній вимір знання, відмінний від об'єкта та його сутнісної, онтологічної (фізичної чи іншої) природи.

Онтологічний вимір репрезентації об'єкта у мисленні людини задає соціальний, правовий вимір, згідно з яким з об'єктом чинять так, яким він $є$ представленим онтологічно. Яку онтологічну сутність має об'єкт, так з ним і вчиняють.

Інша річ - репрезентація як спосіб постання об'єкта у знанні, що постає у вигляді ідеальної предметності знання. Репрезентативність тут створює внутрішній вимір знання, його процесуальність. Спосіб постання об’єкта у знанні виявляє дії, які відбуваються над об’єктом у внутрішній площині знання. Об'єкт розкривається як об'єкт, як об'єктивна, предметна, не залежна від суб'єкта сутність саме через ці дії, які зумовлюють усі трансформації об'єкта в знанні.

Онтогносеологізм зумовлює структуралізацію об'єкта у знанні через філософсько-категоріальні структури і на їх основі. Він набрав розвитку як методологічна парадигма, яка виявляє філософськокатегоріальні передумови пізнання. Постановка питання про філософсько-категоріальні засади фізичної теорії (А. Артюх) створила передумови для переходу до розгляду соціальної зумовленості та соціокультурної детермінації наукового пізнання (Мамчур). Соціокультурна детермінація передбачала введення філософсько-категоріальних структур у внутрішній вимір теорії і теоретичного знання. Ототожнення методологізації з ідеологізацією сприяло науковому дискурсу відтворення філософсько-категоріальних структур «Капіталу» К.Маркса далеко за межами теоретичної політичної економії. Відбулося також уведення їх і у внутрішній вимір природничонаукової теорії. Однак наявність математичного апарату природничонаукової теорії стала фактором, що загальмував, а згодом і зупинив ідеологічне проникнення в глиб природничонаукового знання.

Розробка стандартної моделі наукового знання, яка відбулася на рівні мови наукової теорії, відобразила стандарт виробництва наукового знання - взаємодію емпіричного і теоретичного на рівні мови. Стандартна концепція наукового знання постає у вигляді мови теорії та мови спостереження. Структуралістський підхід до 
природничонаукової, насамперед фізичної, теорії (Снід, Штегмюллер) створив передумови для розкриття формалізованих структур теорії у вигляді сукупності моделей та сфери їх застосувань. Т.Куп після концепції наукових революцій акцентує саме зміну формалізованих структур теорії, запроваджуючи їх розгляд застосувань різних моделей.

Запровадження ідеальної предметності знання дає змогу перейти до дослідження трансформації способу репрезентації об'єкта в знанні. Проблема зростання знання (К. Поппер) розкриває знання в площині взаємодії емпіричного і теоретичного. Перехід від старої теорії до нової через висунення великої кількості гіпотез, їх селекцію та елімінацію так само, як і перехід від старої проблеми до нової, відбувається в лінійній площині взаємодії нових теоретичних форм з емпіричними факторами.

Дослідження еволюції способів подання об'єкта в знанні дає змогу виявити загальні закономірності розвитку й трансформації репрезентації. Однак розгляд усієї сфери знання з точки зору розвитку певного способу подання об'єкта у знанні якісно змінює методологічну ситуацію. Відношення до об'єкта, опосередковане репрезентацією, втрачає свою безпосередність.

Детермінація об'єкта в знанні виявляє свою залежність від ступеня розвитку способу подання об’єкта у знанні. Це дає змогу в рамках одного й того самого типу репрезентації об'єкта у знанні виявити якісні рівні, які відповідають ступеню розвиненості способу подання об'єкта в знанні. Ці рівні відповідають різним ступеням розвитку теоретичної ідеалізації. Так, у Галілея репрезентація відбувається, як безпосереднє заміщення об'єкта чи його властивості певним геометричним репрезентатором.

У «Математичному годиннику» Х.Гюйгенса репрезентація опосередкована гіпотезами, зміст яких викладається у пропозиціях. У І.Ньютона в «Математичних началах натуральної філософії» репрезентація опосередкована впровадженням на початку всіх циклів задач в усіх видах об'єктів загальної онтології. Структура цієї онтології задається у введених на початку роботи онтологічних конструктів - абсолютного простору, абсолютного часу, абсолютної одночасності та ін.

Онтологічні конструкти виходять за межі детермінації об'єктом знання. Конкретних об’єктів у «Математичних началах натуральної 
філософії» багато. Але й вони постають не безпосередньо, а через концептуальні моделі, які стають загальною формою об'єктної детермінації. Так, поряд із класичним «природним» об'єктом - вільним падінням тіл у порожнечі чи Місяцем з'являється «штучний» об’єкт, створений з теоретичних конструктів, - модель тіла, що складається 3 матеріальних точок.

На вищих щаблях геометричної репрезентації відбувається реалізація детермінації об'єкта на двох рівнях - концептуальних моделей та всезагальної онтологічної конструкції, яка відтворює будову природи «як такої». Всезагальність онтологічних конструктів І.Ньютона тривалий час давала підстави для розгляду їх поряд 3 філософськими категоріями, чи навіть як філософські категорії (простір, час та ін.).

Отже, когнітивні особливості відтворення об'єкта у знанні дають змогу, поряд із детермінацією об'єктом і соціальними комунікаціями, виокремити особливий вид детермінації - детермінацію знаннєвої, когнітивної форми, яка відкриває в значенні ідеальної предметності знання внутрішній вимір знання. Це дає змогу 3'ясувати автономність внутрішнього виміру знання від внутрішньої структури та природної сутності об'єкта.

Як бачимо, впровадження у розгляд способу представлення об’єкта в знанні розкриває детермінацію об'єкта через ідеальну предметність знання. Дослідження еволюції способу представлення об'єктів у знанні виявляє розвиток теоретичних ідеалізацій - від безпосередньої репрезентації - заміщення природного об'єкта геометричним відрізком до застосування гіпотез, онтологічних конструктів та концептуальних моделей.

Розкриття способу представлення об'єкта у знанні як знаннєвої детермінації поглиблюється, коли враховується залежність чинників розвитку певного виду репрезентації об'єктів у знанні від сфери самого знання.

\section{ЛIТЕРАТУРА}

1. Ведмедєв М.М. Культурні ресурси продуктивного мислення. - Суми, 2011. $-216 \mathrm{c}$.

2. Галилей Г. Беседы и математические доказательства, касающиеся двух новых отраслей науки // Галилей Г. Избр. труды : В 2-х т. - М., 1964. -

ISSN2078-8142 Мультиверсум. Філософський альманах.-2015.-Випуск 3-4(141-142) 135 


\section{T. 2. - C. 109-404.}

3. Гюйгенс $X$. Маятниковые часы // Гюйгенс X. Три мемуара по механике : пер., ред. и примеч. К.К.Баумгарта. - М., 1951. - 378 с.

4. Демьянков В.3. Когнитивная лингвистика как разновидность интепретирующего подхода // Вопросы языкознания. - 1994. - № 4. - С. 17-33.

5. Князева Е.Н. Эндофизика и временные шкалы виртуального восприятия // Вопросы философии. - 2007. - № 2. - С.80-96.

6. Кузнецов В. Про стан і перспективи розвитку методологічних досліджень науки // Філософська думка. - 2005. - № 6. - С.3-31.

7. Найссер У. Познание и реальность: Смысл и принципы когнитивной психологии : пер. с англ. В.В.Лучкова. Вступит. ст. и общ. ред. Б.М.Величковского. - М., 1981. - 230 с.

8. Ньютон И. Математические начала натуральной философии : пер. с латин., примеч. и пояснения А.Н.Крылова // Крылов А.Н. Собрание трудов. - М.-Л., 1936. - Т. 7. - 696 с.

9. Радионова С.А. Репрезентация // Постмодернизм. Энциклопедия. Сост. А.А.Грицанов, М.А.Можейко [Електронний ресурс]. - Режим доступу: http://www.infoliolib.info/philos/postmod/represent.html

10. Ратников B.C. О статусе понятия репрезентации в философии науки. // Філософські читання пам'яті Павла Копніна : міжнар. наук. конф. Київ, 4-5 жовт. 1996 р. - К. - С. 118-122.

11. Ребеко T.A. Ментальная репрезентация как формат хранения информации. // Ментальная репрезентация: динамика и структура. - М., 1998. - C. $25-54$.

12. Черникова И.В. Современная наука и научное познание в зеркале философской рефлексии // Вестн. Моск. ун-та. - Сер. 7. Философия. 2004. - №6. - C. 94-103.

13. Brachman R.J., Levescue H.J. and Reiter R. Ed. Proceedings of the First International Conference on Principles of Knowledge Representation and Reasoning // Los Altos. CA : Morgan Kaufmann, 1989. - 520 p.

14. Brachman R.J., Levesque H.J. Knowledge Representation and Reasoning. CA.: Morgan Kaufmann, 2004. - 381 p.

15. Engelkamp J., Denis M. Multimodal Approach to the Issue of Mental Representations // Centre d'Études de Psychologie Cognitive. - 1989. Doc. No. 65. - P.1-26.

16. Engelkamp J., Pechman Th. Kritische Anmerkungen zur Begriff der mentalen Reprasentation // Sprache \& Kognition. - 1988. - Vol. 7. - P.2-11.

17. Pitt D. Mental Representation // The Stanford Encyclopedia of Philosophy (Spring 2007 Edition), Edward N. Zalta(ed.) [Електронний ресурс]. - Peжим доступу: http://plato.stanford.edu/archives/spr2007/entries/mentalrepresentation/ 
Рубанець О.О. Когнітивні особливості відтворення об 'єкта в знанні.

У статті розглядається застосування репрезентацій у методологічній реконструкції еволюції систем знання. Доведено, зокрема, що перехід від лінгвістичного до когнітивного повороту в науці зумовлений запровадженням ментальної репрезентації. Проаналізовано різні напрями в іiї дослідженні. 3'ясовано, що вона постає як складова психічної реальності та iï моделювання в науці. Перехід до методологічної реконструкції в еволюції систем знання вимагає розгляду репрезентації. Досліджено можливість застосування менталістських і феноменологічних розробок репрезентації у формах об’єктивного наукового знання. Показано, що в системах об'єктивного знання потрібно розглядати репрезентацію у вигляді ідеалізованої предметності знання. Вона являе собою результат когнітивної активності людини у вигляді способу постання об'єкта в знанні. Запровадження ідеалізованої предметності дає змогу ввести в розгляд новий вид детермінації. Досі приділяли увагу детермінації об’єкта у знанні та їі філософсько-категоріальним засадам. Ідеалізована предметність виявляє внутрішній вимір знання. Це дає можливість глибше розкрити відмінність знання від об'єкта й від ментальних станів суб'єкта. Досліджено еволюцію систем способу подання, представлення об'єкта в знанні на різних етапах розвитку наукової теорії.

Ключові слова: ідеалізована предметність знання, репрезентація, ментальна репрезентація.

Рубанеи А.М. Когнитивные особенности воссоздания объекта в знании.

В статье рассматривается применение репрезентаций в методологической реконструкции эволюции систем знания. Доказано, что переход от лингвистического к когнитивному повороту в науке обусловлен введением в рассмотрение ментальной репрезентации. Анализируются различные направления в ее исследовании. Выяснено, что она выступает как составляющая психической реальности и ее моделирования в науке. Переход к методологической реконструкции в эволюции систем знания требует рассмотрения репрезентации. Исследована возможность применения менталистских и феноменологических разработок репрезентации в формах объективного научного знания. Показано, что в системах объективного знания нужно рассматривать репрезентацию в виде идеализированной предметности знания. Она выступает как результат когнитивной активности человека в виде способа представления объекта в знании. Введение идеализированной предметности позволяет ввести в рассмотрение новый вид детерминации. До сих пор уделялось внимание детерминации объекта в знании и ее философско-категориальным основам. Идеализированная предметность обнаруживает внутреннее измерение знания. Это дает возможность более глубоко раскрыть отличие знания от объекта и от ментальных состояний 
субъекта. Исследована эволюция систем способа представления объекта в знании на разных этапах развития научной теории.

Ключевые слова: идеализированная предметность знания, репрезентация, ментальная репрезентация.

Rubanets A. Cognitive features playback object in knowledge.

In the article the use of representations of methodological reconstruction of the evolution of knowledge. The transition from the linguistic turn to cognitive science due consideration of the introduction of mental representation. Different directions in the study of mental representation. It was found that mental representation appears as part of psychic reality and its simulation in science. Go to methodological reconstruction of the evolution of knowledge requires consideration of representation. The possibility of the use of Cognitive and Mentalist development and phenomenological representations in the forms of objective scientific knowledge. It is shown that systems should be considered objective knowledge representation in the form of idealized objectivity of knowledge. It appears as the result of human cognitive activity as a way of presenting the object in knowledge. Introduction idealized objectivity gives consideration to enter into a new kind of determination. Still considered in the determination of the object of knowledge and philosophical categorical principles. Idealized objectivity reveals the inner dimension of knowledge. It gives an in-depth knowledge to reveal the difference of the object and the subject of mental states. The evolution of mode of presentation in knowledge at different stages of development of scientific theory.

Key words: idealized objectivity of knowledge representation, mental representation. 